Separate Schools 



\section{Separate Schools}

Gender, Policy, and Practice

\section{in Postwar \\ Soviet Education}

\section{E.Thomas Ewing}

min

NORTHERN

ILLINOIS

UNIVERSIT Y

PRESS

DeKalb 
(C) 2010 by Northern Illinois University Press

Published by the Northern Illinois University Press, DeKalb, Illinois 60115

All Rights Reserved

Design by Shaun Allshouse

Library of Congress Cataloging-in-Publication Data

Ewing, E. Thomas

Separate schools: gender, policy, and practice in postwar Soviet education /

E. Thomas Ewing.

p. $\mathrm{cm}$.

Includes bibliographical references and index.

ISBN 978-0-87580-434-7 (clothbound : alk. paper)

1. Single-sex schools-Soviet Union-History. 2. Sex differences in education-Soviet Union. 3. Education and state-Soviet Union. I. Title.

LB3067.7.S65.E85 2010

$371.821-\mathrm{dc} 22$

2010019100 


\section{For Amy and Claire}


